\title{
КАРАНІСТЬ СЕПАРАТИЗМУ ЗА КРИМННАЛЬНИМ КОДЕКСОМ УКРАЇНИ
}

\author{
СТИРАНКА Михайло Богданович - аспірант кафедри кримінально- \\ правових дисциплін Львівського державного університету внутрішніх справ \\ DOI 10.32782/EP.2021.22
}

Визначено систему складів злочинів, які регламентують кримінальну відповідальність за посягання на територіальну иілісність і недоторканність, а також територіальний устрій держави. До них запропоновано відносити: дї, спрямовані на насильницьку зміну чи повалення конституиійного ладу або на захоплення державної влади (ст. 109 КК Украӥни); посягання на територіальну иілісність $і$ недоторканність України (ст. 110 КК України); бінансування дій, вчинених з метою насильницької зміни чи повалення конституційного ладу або захоплення державної влади, зміни меж території або державного кордону України (ст. 110-2 КК України); державна зрада (ст. 111 КК України); пропаганда війни (ст. 436 КК Украӥни); планування, підготовка, розв'язування та ведення агресивноӥ війни (ст. 437КК Украӥни); найманство (ст. 447 КК України).

Встановлено ступінь тяжкості проявів сепаратизму, з'ясовано обгрунтованість визначення меж покарань. Розглянуто співвідношення покарання за сепаратизм та інших однотипних злочинів. Констатовано, що санкцї аналізованих кримінально-правових норм вони є простими, кумулятивними, одиничними, альтернативними та відносно визначеними.

Ключові слова: сепаратизм, територіальна цілісність та недоторканність, територіальний устрій, національна безпека, кримінальна відповідальність, склад злочиHy.

\section{Постановка проблеми}

Кожен факт учинення кримінального правопорушення передбачає відповідну реакцію з боку держави, що $є$ необхідною умовою забезпечення реалізації правових норм та запобігання їх порушенням у майбутньому. Наслідки вчинення того чи іншого посягання визначаються у кримінально-правовій санкції, яка становить законодавчу оцінку небезпечності діяння, що передбачене в конкретній нормі, а також відображає позитивні та негативні аспекти діяльності зі соціального конструювання у правовій сфері, досягнення та невдачі законодавця, оскільки вона є ії кінцевим результатом [1, с. 2]. Таким чином, аналіз караності за вчинення кримінальних правопорушень, зокрема тих, які посягають на територіальну цілісність і недоторканність, а також територіальний устрій держави, має важливе значення, оскільки надає можливість дослідити вид і розмір покарання, його справедливість та ефективність.

\section{Стан дослідження}

У наш час деякі аспекти вказаної проблеми розглядали у своїх працях В. С. Батиргареєва, Д. С. Зоренко, Ю. В. Ауценко, Н. М. Парасюк, С. Ю. Плецький, О. В. Попович, А. В. Савченко, Г. В. Татаренко та ін. Очевидно, що здійснені дослідження мають важливе значення як для сучасної науки, так і для практики. Однак, як правило, положення, що стосуються питань 


\section{Кримінальне право, кримінальний процес та криміналістика}

караності за сепаратизм, у таких роботах носять констатуючий або фрагментарний характер.

Таким чином, основною метою цієї статті є з'ясування питань караності сепаратизму за КК України.

\section{Виклад основних положень}

Питання щодо караності сепаратизму за КК України доречно розглядати поетапно:

1) встановити ступінь тяжкості аналізованих злочинів, з'ясувати види покарань, а також обгрунтованість визначення їх меж;

2) розглянути співвідношення покарання за сепаратизм та інші однотипні злочини.

Найперше потрібно визначити належність учиненого злочину до певної категорії тяжкості, що зумовлює потребу врахування його характеру (якісна характеристика суспільної небезпеки, яка визначається передусім важливістю суспільних відносин, на які посягає злочин) та ступеня суспільної небезпеки (спосіб учинення злочину, форма вини, мотив і мета, характер і ступінь тяжкості наслідків тощо). Про це, зокрема, йдеться у Постанові Пленуму ВСУ «Про практику призначення судами кримінального покарання» від 24 жовтня 2003 № 7, де у п. 3 зазначено, що визначення ступеня тяжкості злочинів здійснюється із врахуванням положень ст. 12 КК України, а також особливостей конкретного злочину й обставин його вчинення.

Із положень ст. 12 КК України випливає, що за ступенем суспільної небезпеки прояви сепаратизму є нетяжкими злочинами (чч. 2, 3 ст. 109, ч. 1 ст. 110, ч. 1 ст. 110-2, ст. 436 КК України), тяжкими (ч. 1 ст. 109, ч. 2 ст. 110, чч. 2, 3, 4 ст. 110-2, чч. 1, 4 ст. 447 КК України) та особливо тяжкими (ч. 3 ст. 110 , ч. 1 ст. 111, ст. 437, чч. 2, 3 ст. 447 КК України). Натомість таких видів посягання на територіальну цілісність і недоторканність, а також територіального устрою держави, які б самі собою становили кримінальні проступки, у КК України не передбачено. Такий стан речей можна пояснити тим, що захищеність території є однією з умов розвитку держави та суспільства загалом. Інакше кажучи, прояви сепаратизму виступають як внутрішні та зовнішні загрози у всіх сферах функціонування держави, що підривають не лише забезпечення її сталого розвитку, а й умови реалізації конституційних прав і свобод людини. 3 огляду на це вони характеризуються високим ступенем суспільної небезпеки.

у подальшому необхідно визначити види покарань, а також обгрунтованість установлення їх меж. Відразу наголосимо, що за прояви сепаратизму зазвичай встановлені покарання, які передбачають ізоляцію від суспільства (ч. 1 ст. 109, ст. 110 , ст. 110-2, ст. 111 , ст. 437, ст. 447 КК України), що вкотре підкреслює важливість об'єкта кримінально-правової охорони. Аише в окремих статтях як альтернатива покаранню у виді позбавлення волі за сепаратизм передбачено обмеження волі (чч.2, 3 ст. 109 КК України), виправні роботи або арешт (ст. 436 КК України). Окрім того, законодавець щодо осіб, які визнані винними за вчинення одного зі злочинів, що посягають на територіальну цілісність і недоторканність, а також територіальний устрій держави, передбачає можливість застосування декількох покарань одночасно, тобто окрім основного ще й додаткове, а саме: позбавлення волі 3 конфіскацією майна (ст. 109, ч. 1, 2 ст. 110, ст. 111 , ч. 2 ст. 447 КК України), позбавлення волі або довічне позбавлення волі з конфіскацією майна (ч. 3 ст. 110, ч. 3 ст. 447 КК України), позбавлення волі 3 позбавленням права обіймати певні посади або займатися певною діяльністю та 3 конфіскацією майна (ст. 110-2 КК України).

У теорії кримінального права санкції класифікують за такими критеріями: за наявністю чи відсутністю додаткових покарань (прості та кумулятивні); за можливістю обрання судом покарання (абсолютно визначені та відносно визначені); за кількістю основних видів покарань (одиничні та альтернативні) [2, с. 180-181]. Отож із аналізу санкцій статей за прояви сепаратизму констатуємо, що вони є простими, 
тобто такими, які містять лише основне покарання без наявності додаткових покарань (ст. 436, ст. 437, чч. 1, 4 ст. 447 КК України), кумулятивними, які поряд 3 основним покаранням передбачають ще й додаткове (ст.ст. 109, 110, 110-2, 111 , чч. 2, 3 ст. 447 КК України), одиничними, які містять лише одне основне покарання, що виключає можливість суду обрати інший вид покарання (ч. 1 ст. 109, чч. 1, 2 ст. 110, ст. 110-2, ст. 111 , ст. 437, чч. 1, 2, 4 ст. 447 КК України), альтернативними, тобто такими, які містять вказівку на два або більше видів основних покарань (чч. 2, 3 ст. 109, ст. 436, ч. 3 ст. 447 КК України) та відносно визначеними, у яких передбачено покарання із визначенням його мінімальної та максимальної (або лише максимальної) межі покарання (ст. 109, чч. 1, 2 ст. 110 , ст. 110-2, ст. 111 , ст. 436, ст. 437, чч. 1, 2, 4 ст. 447 КК України).

При побудові санкцій кримінальноправових норм законодавець має керуватися певними принципами та дотримуватися низки обов'язкових вимог, яких висувається чимало [3, с. 37]. 3 огляду на це, вирішуючи питання щодо обгрунтованості визначення меж покарання за прояви сепаратизму, доцільно вдатися до правил конструювання кримінально-правових санкцій, що надасть змогу простежити неточності чи прорахунки законодавця в цій частині, а також визначити, чи встановлені санкціями аналізованих статей КК України види й розміри покарань враховують характер і ступінь суспільної небезпечності діяння.

Щодо більшості злочинів, які посягають на територіальну цілісність і недоторканність, а також територіальний устрій держави, як засіб диференціації кримінальної відповідальності та покарання, законодавець використовує кваліфікуючі та (чи) особливо кваліфікуючі ознаки, що, порівняно 3 основним складом злочину, суттєво підвищує рівень суспільної небезпечності злочину. Зважаючи на це, видається закономірним, що в такому випадку покарання повинно лише посилюватись. Водночас як виняток у такому випадку може бути наявність самостійних складів злочинів, які, так би мовити, є незалежними одне від одного (ч. 1 та ч. 2 ст. 109, ч. 1 та ч. 2 ст. 110-2, ч. 3 та ч. 4 ст. 447 КК України), а тому конструкції санкцій у цьому разі є обгрунтованими.

Власне одним із правил конструювання кримінально-правових санкцій $є$ таке: «драбина» санкцій за основний, кваліфікований та особливо кваліфікований склади злочину повинна залежати від особливостей конкретного складу злочину. При цьому максимальний розмір покарання за злочин із основним складом одночасно може бути й мінімальним розміром покарання за злочин із кваліфікованим складом [4, с. 140].

Аналіз санкцій статей, які регламентують кримінальну відповідальність за прояви сепаратизму, дає підстави для висновків, що це правило законодавець врахував при побудові санкцій ст. 110 (ч. 1 - від трьох до п'яти років; ч. 2 - від п'яти до десяти років; ч. 3 - від десяти до п'ятнадцяти років) та ст. 110-2 (ч. 1 - від трьох до п’яти років; ч. 2 - від п'яти до семи років) КК України.

Утім в інших випадках наведену вимогу законодавцем порушено. Прикладом слугує санкція ст. 437 КК України. Так, за дії, які полягають у плануванні, підготовці або розв'язуванні агресивної війни чи воєнного конфлікту, а також участь у змові, що спрямована на вчинення таких дій, передбачено покарання у виді позбавлення волі на строк від семи до дванадцяти років позбавлення волі. Натомість за ведення агресивної війни або агресивних воєнних дій таким покаранням є позбавлення волі на строк від десяти до п’ятнадцяти років. Схожа ситуація простежується і в санкції статті 447 (ч. 1 - від п’яти до десяти років; ч. 2 - від семи до дванадцяти років; ч. 3 - від десяти до п'ятнадцяти років) КК України. Такий стан речей є свідченням невдалої побудови санкцій, оскільки не повністю додержано логіки окремих розмірів покарання. 3 огляду на це не слід виключати можливість призначення судом за вчинення менш тяжкого злочину однакового або більш суворого покарання, ніж за тяжкий злочин. 


\section{Кримінальне право, кримінальний процес та криміналістика}

Наступним правилом побудови кримінально-правових санкцій є положення, відповідно до якого введення додаткових покарань необхідно проводити за схемою: санкція без додаткового покарання (ч.1), санкція 3 факультативним додатковим покаранням (ч.2), санкція 3 імперативним додатковим покаранням (ч. 3) [5, с. 234-236]. Це правило не було враховано законодавцем при конструюванні санкцій аналізованих статей, оскільки в окремих випадках як і в основному, так і в кваліфікованому та особливо кваліфікованому складах злочинів передбачено додаткові покарання у виді конфіскації майна (чч. 2, 3 ст. 109, ст. 110, ст. 110-2, чч. 2, 3 ст. 447 КК України) та позбавлення права обіймати певні посади або займатися певною діяльністю (ст. 110-2 КК України). Втім, видається, це правило не слід вважати універсальним, оскільки закономірно, що воно може не «спрацьовувати» у тих злочинах, які характеризуються підвищеним ступенем суспільної небезпеки, де вже в основному складі злочину передбачено безальтернативне покарання у виді позбавлення волі. Водночас доводиться констатувати, що встановлення додаткового покарання у виді конфіскації майна не у всіх випадках є виправданим кроком законодавця, оскільки суперечить положенням Загальної частини КК України. Зокрема, у ч. 2 ст. 58 КК України вказується, що конфіскація майна встановлюеться за тяжкі та особливо тяжкі корисливі злочини, а також за злочини проти основ національної безпеки України та громадської безпеки незалежно від ступеня їх тяжкості. Водночас чч. 2, 3 ст. 447 «Найманство» КК України не підпадає під цю категорію, що $є$ свідченням порушення законодавчих правил встановлення покарання.

Ще одним правилом побудови санкцій кримінально-правових норм є положення, відповідно до якого санкції норм, які передбачають однорідні за характером і ступенем суспільної небезпеки діяння, мають бути узгоджені [6, с. 32]. Зокрема, аналізуючи види та міри покарання за прояви сепаратизму, є підстави вважати, що санкції окремих кримінально-правових норм не відповідають типовій суспільній небезпеці злочину, що свідчить про невиваженість караності таких діянь. Приміром, простежуються, м'яко кажучи, неточності у конструюванні санкцій за злочини, передбачені ч. 2 ст. 109 та ч. 1 ст. 110 КК України. Якщо здійснювати їх порівняння, то виходить, що за публічні заклики до насильницької зміни чи повалення конституційного ладу, зокрема територіального устрою, передбачено менш суворе покарання (ч. 2 ст. 109 - обмеження волі на строк до трьох років або позбавлення волі на той самий строк з конфіскацією майна або без неї), аніж за публічні заклики до вчинення дій з метою зміни меж території або державного кордону України (ч. 1 ст. 110 - позбавлення волі на строк від трьох до п'яти років 3 конфіскацією майна або без неї). Такий стан речей не можна назвати виправданим, оскільки, відповідно до санкцій аналізованих статей, самі по собі дії, які посягають на територіальний устрій держави, є більш небезпечними (ч. 2 ст. 109 - позбавлення волі на строк від п'яти до десяти років 3 конфіскацією майна або без неї), ніж ті, що зазіхають на iii територіальну цілісність і недоторканність (ч. 1 ст. 110 - позбавлення волі на строк від трьох до п'яти років 3 конфіскацією майна або без неї).

Ще одним свідченням невиваженого підходу до конструювання кримінальноправових санкцій є санкція ст. 110-2 КК України. Нагадаємо, що ця стаття була введена в дію Законом від 19 червня 2014 № 1533-VII з метою запобігання підтримці сепаратистських настоїв і фактичного посилення відповідальності за фінансування таких дій. Назагал фінансування проявів сепаратизму є нічим іншим як пособництвом у злочинах, передбачених ст. 109 та 110 КК України, або їх організацію. Проте за відсутності цієї статті у КК України такі дії отримали би кримінально-правову оцінку за ст. 109 чи 110 КК України з урахуванням інституту співучасті (ч. 3 або 5 ст. 27). Так, санкція ч. 1 ст. 110-2 КК України практично перегукується зі санкцією ч. 1 ст. 110 КК України, яка регламентує кримінальну відповідальність за посяган- 
ня на територіальну цілісність і недоторканність України, оскільки вид та розмір покарання є однаковим (позбавлення волі на строк від трьох до п'яти років; як додатковий обов'язковий вид покарання передбачено позбавлення права обіймати певні посади або займатися певною діяльністю, що не можна сприйняти схвально. Зокрема, 3 аналізу диспозиції ст. 110-2 КК України випливає, що фінансування сепаратизму не пов'язане із використанням особою свого службового становища, оскільки у ній відсутня вказівка на спеціальний суб'єкт (службову особу або представника влади), а тому застосування такого виду покарання є алогічним.

Аналіз санкції ч.2 ст.110-2 КК України, яка регламентує кримінальну відповідальність за фінансування дій, учинених 3 метою насильницької зміни чи повалення конституційного ладу, дає змогу констатувати, що законодавець їі послабив порівняно зі санкцією «материнської» статті (ч. 1 ст. 109 КК України). Зокрема, за фінансування сепаратизму (посягання на територіальний устрій) передбачено основне покарання у виді позбавлення волі на строк від п'яти до семи років, натомість безпосереднє посягання на територіальний устрій карається суворіше (ч. 1 ст. 109 - позбавленням волі на строк від п'яти до десяти років).

Дещо схожа ситуація трапляється i під час аналізу караності подібних діянь за ознакою спричинення тяжких наслідків. Їх настання внаслідок умисних дій, учинених із метою зміни меж території або державного кордону України на порушення порядку, встановленого Конституцією України, карається позбавленням волі на строк від десяти до п’ятнадцяти років або довічним позбавленням волі 3 конфіскацією майна чи без неї (ч. 3 ст. 110 КК України). Натомість за спричинення тяжких наслідків через фінансування таких дій передбачено менш суворе основне покарання (ч. 4 ст. 110-2 - позбавлення волі на строк від восьми до десяти років). Зі сказаного випливає, що введення в діюст. 110-2 КК України фактично свідчить про послаблення кримінальної відпові- дальності за прояви сепаратизму, оскільки за їі відсутності такі 6 дії карались суворіше. Отже, невиваженість санкцій цієї норми, а також фактично повторна криміналізація дій, передбачених ст. 109 та ст. 110 КК України у виді фінансування сепаратизму, засвідчує недоцільність існування ст. 110-2 у КК України, отож вона мусить бути виключена.

\section{Висновки}

Аналіз караності сепаратизму за КК України демонструє, що за ступенем суспільної небезпеки такі злочини є нетяжкими, тяжкими та особливо тяжкими. Кримінальним проступкам, як найменш небезпечній категорії, немає місця у відповідній системі посягань, оскільки захист територіальної цілісності і недоторканності, а також територіального устрою держави належить до найважливіших їі функцій та 6 пріоритетом національних інтересів. Водночас доводиться констатувати про порушення законодавчих правил встановлення покарання за деякі прояви сепаратизму, оскільки санкції окремих кримінально-правових норм не відповідають типовій суспільній небезпеці злочину, що є свідченням того, що законодавець при їх конструюванні не врахував характеру і ступеня суспільної небезпечності діяння.

\section{Miтepaтypa}

1. Орловська Н. А. Проблемні питання побудови кримінально-правових санкцій в контексті впливу на неповнолітніх правопорушників. Часопис Академї̈ адвокатури. 2010. № 9 (4). С. 1-7.

2. Арманов М. Г. Покарання за вчинення злочинів, передбачених статтями 355 та 356 КК України. Збірник наукових праць Харківського начіонального педагогічного університету імені Г. С. Сковороди. Серія «Право». 2011. Вип. 17. С. 177-186.

3. Калмиков Д. Аналіз санкції статті 150 Кримінального кодексу України. Вісник Національной академї прокуратури України. 2012. № 4. C. 37-42.

4. Карпец И. И. Наказание. Социальные, правовые и криминологи- 
ческие проблемы. М. : Юрид. лит., 1973. $228 \mathrm{c}$.

5. Аесниевски-Костарева Т. А. Дифференциация уголовной ответственности. Теория и законодательная практика. М. : HOPMA, 1998. 296 с.

6. Дементьев С. И. Построение уголовно-правовых санкций в виде лишения свободы. Ростов-на-Дону : Изд-во Рост. ун-та, 1986. 157 с.
The system of corpus delicti, which regulates criminal liability for encroachment on territorial integrity and inviolability, as well as the territorial structure of the state, has been determined. It is proposed to include: actions aimed at forcible change or overthrow of the constitutional order or seizure of state power (Article 109 of the Criminal Code of Ukraine); encroachment on the territorial integrity and inviolability of Ukraine (Article 110 of the Criminal Code of Ukraine); financing of actions committed for the purpose of forcible change or overthrow of the constitutional order or seizure of state power, change of borders of the territory or state border of Ukraine (Article 110-2 of the Criminal Code of Ukraine); treason (Article 111 of the Criminal Code of Ukraine); propaganda of war (Article 436 of the Criminal Code of Ukraine); planning, preparation, resolution and conduct of aggressive war (Article 437 of the Criminal Code of Ukraine); mercenary activities (Article 447 of the Criminal Code of Ukraine).

The severity of separatism has been established, and the validity of the limits of punishment has been clarified. The ratio of punishment for separatism and other similar crimes is considered. It is stated that the sanctions of the analyzed criminal law norms are simple, cumulative, single, alternative and relatively definite.

Key words: separatism, territorial integrity and inviolability, territorial organization, national security, criminal responsibility, corpus delicti. 